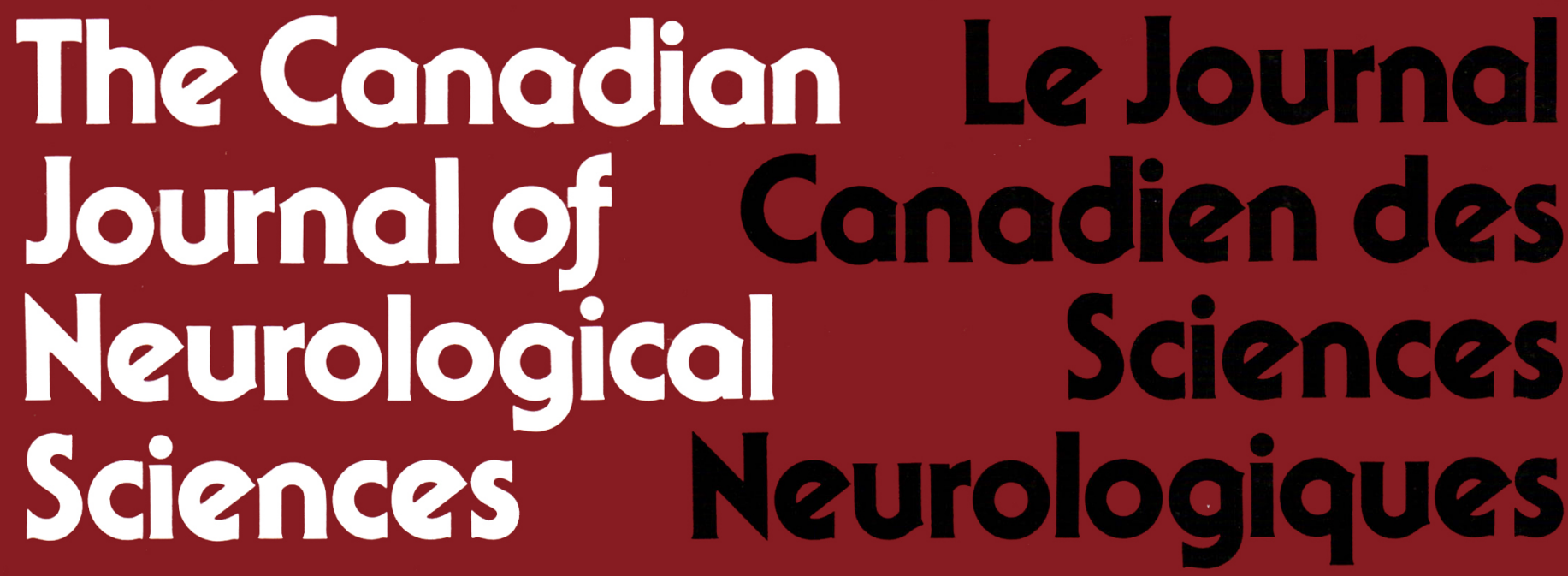

\title{
SPECIAL FEATURES
}

1985 Silversides Lecture: Unusual Vascular Events in the Territory of the

Posterior Cerebral Artery ............................................................ Fisher Review Article: The Nucleus Basalis of Meynert ............ Cheryl Ezrin-Waters

Review Article: Neurological Disorders Associated with Mitral Valve

Prolapse Alan C. Jackson

\section{ORIGINAL ARTICLES}

Intrathecal Synthesis of Autoantibodies to Myelin Basic Protein in Multiple Sclerosis ............................................. Ingrid Catz and Kenneth G. Warren Effect of Methylprednisolone on CSF IgG Parameters, Myelin Basic Protein and Anti-Myelin Basic Protein in Multiple Sclerosis Exacerbations

Kenneth $G$. Warren, Ingrid Catz, Verona M. Jeffrey and Dorothy I. Carroll

Cytoplasmic RNA in Nervous System Tumours in Children: A Fluorochromic Histochemical Study using Acridine Orange ................... Harvey B. Sarnat, Bernadette Curry, N.B. Rewcastle and Cynthia L. Trevenen

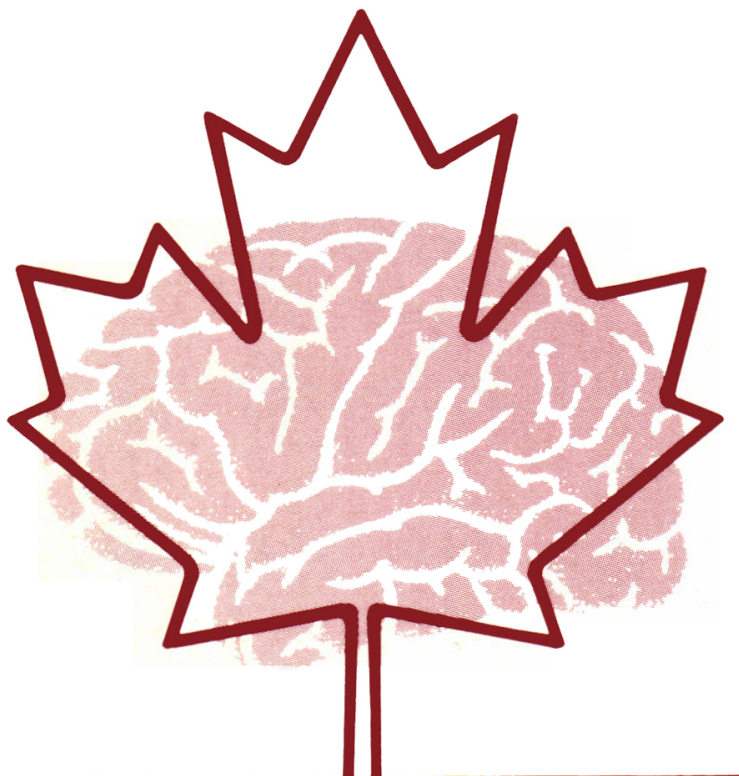

XXI Canadian Congress of

Neurological Sciences London, Ontario

June 24 - 28, 1986

\section{The Official Journal of}

The Canadian Neurological Society

The Canadian Neurosurgical Society

The Canadian Society of Clinical Neurophysiologists

The Canadian Association for Child Neurology 


\section{When patients show prominent dyskinesia \\ or wearing-off reactions on long-term levodopa}




\title{
The Canadian Journal of Neurological Sciences
}

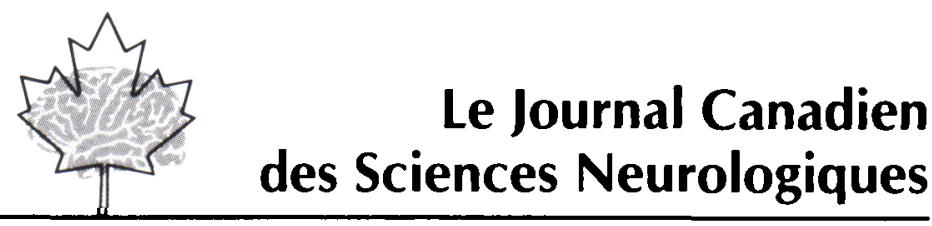

\author{
Editor/Rédacteur en chef Robert G. Lee Calgary \\ Associate Editors/Rédacteurs associés André Barbeau Montreal \\ Harvey B. Sarnat Calgary \\ Founding Editor/Fondateur-rédacteur Robert T. Ross Winnipeg \\ Book Review Editor/Rédacteur de critiques de livres T. Peter Seland Calgary \\ Managing Editor/Adjoint administratif Sally A. Gregg Calgary \\ News Editor/Rédacteur des Nouvelles Thomas P. Morley Toronto
}

\section{Editorial Board/Conseil Scientifique}

Albert J. Aguayo Montreal
Henry I.M. Barnett London
Larry Becker Toronto
Paul Bédard Quebec
George Ebers London
Guy Geoffroy Montreal
Yves Lamarre Montreal
William I. Logan Toronto
Morton Low Vancouver
John Murphy Toronto
Thomas I. Murray Halifax

André Olivier Montreal

Donald Paty Vancouver

Sidney I. Peerless London

Terry Picton Ottawa

Jean Reiher Sherbrooke

Leo P. Renaud Montreal

Matthew W. Spence Halifax

John Stewart Montreal

Charles Tator Toronto

Simon Verret Quebec

Bryce Weir Edmonton

Publications Committee/Comité de Rédaction

John Wherrett Toronto

Terry Myles Calgary
Andrew Eisen Vancouver

John Tibbles Halifax

The Official Journal of:/La Revue Officielle de:

The Canadian Neurological Society

La Société Canadienne de Neurologie

President/Président - Robert F. Nelson

Secretary-Treasurer/ - Garth M. Bray,

Secrétaire-Trésorier 650 Cedar Avenue,

Montreal, Quebec

H3G IA4

The Canadian Society of Clinical Neurophysiologists La Société Canadienne de Neurophysiologues Clinics PresidentPrésident - Terence Picton Secretary-Treasurer/ - R. Gordon Blair Secrétaire-Trésorier 25 Leonard Avenue

Suite 309

Toronto, Ontario

M5T 2R2
The Canadian Neurosurgical Society La Société Canadienne de Neurochirurgie

President/Président - Charles Tator

Secretary-Treasurer/ - Alain Godon,

Secrétaire-Trésorier 12361 Notre-Dame-des Anges St., Montreal, Quebec

H4) $2 \mathrm{C} 3$

The Canadian Association for Child Neurology L'Association Canadienne de Neurologie Pédiatrique President/Président - Frederick Andermann Secretary-Treasurer/ - Daune L. McGregor, Secrétaire-Trésorier Hospital for Sick Children 555 University Avenue Toronto, Ontario M5G $1 \times 8$

The Canadian Journal of Neurological Sciences is published quarterly by University of Calgary Press. The annual subscription rate is $\$ 40.00$ for Canada and the U.S.A. $\$ 44.00$ elsewhere Interns, Residents Pre- and Post-Doctoral Students $\$ 20.00$ per annum. Single copies $\$ 12.00$ each. All communications and subscriptions should be sent to the Editor, Canadian lournal of Neurological Sciences, Room 1496, Faculiy of Medicine, University of Calgary, 3330 Hospital Drive N.W., Calgary, Alberta, Canada T2N 4N1. Telephone: (403) 220-3062.

COPYRIGHT $e 1985$ by THE CANADIAN IOURNAL OF NEUROLOGICAL SCIENCES INC. No part of this journal may be reproduced in any form without the prior permission of The Canadian Journal of Neurological Sciences. Mailed under second class registration number 3307. Postage paid at Calgary, Alberta. This journal is indexed by inder Medicus, Excerpta Medica and Current Contents - Clinical Practice and Life Sciences.

Le Journal Canadien des Sciences Neurologiques est publié trimestriellement par les Presses de l'Université de Calgary. L'abonnement annuel est de \$40.00 pour le Canada et les Etats-Unis: $\$ 44.00$ ailleurs. Internes, résidents, fellows pré et post-doctoral: $\$ 20.00$ par an. Toutes les communications et les abonnements doivent être adressés à l'Editeur, Journal des Sciences Neurologiques, chambre 1496. Faculté de Médecine, Université de Calgary, 3330 Hospital Drive N.W., Calgary, Alberta, T2N 4N1. Téléphone (403) $220-3062$.

DROITS D'AUTEUR E 1985: THE CANADIAN IOURNAL OF NEUROLOCICAL SCIENCES INC. Aucune partic de ce lournal ne peut être reproduite, sous quelque forme que ce soit, sans la permission préalable du Journal Canadien des Sciences Neurologiques. Posté sous permis de second classe no 3307 . Port payé à Calgary, Alberta. Le lournal est ciłé et indexé dans Index Medicus, Excerpta Medica et Current Contents - Clinical Practice et Life Sciences.

Advertising representative/Représentant de publicité Keith Health Care Communications, 289 Rutherford Road S.,

Suite 11. Brampton, Ontario, Canada L6W 3R9 - (416) 457-8009

Printer/Imprimeur McAra Printing Limited, 105, 2507-12th Street N.E., Calgary, Alberta T2E 7L5

ISSN $0317 \cdot 1671$ 


\section{Frequent problems of long-term levodopa therapy ${ }^{8}$}

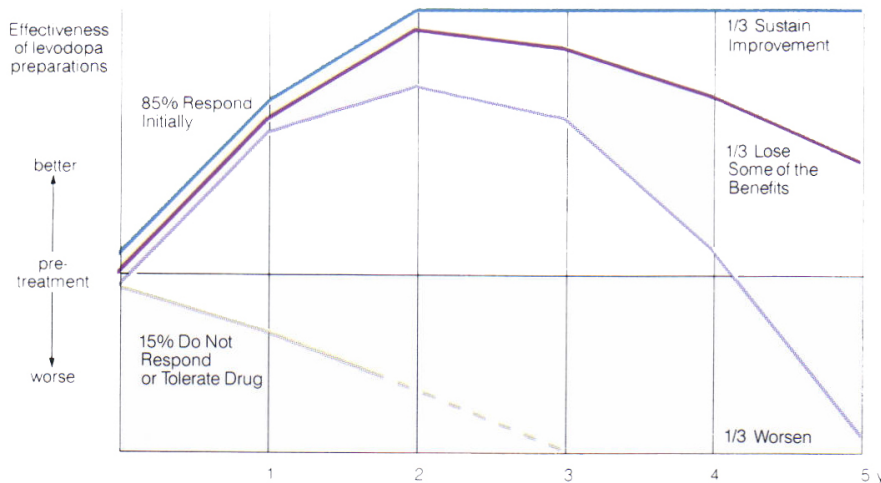

With time, the benefits of levodopa can decline, and patients may demonstrate prominent dyskinesia or signs of wearing-off such as:

$\square$ performance fluctuations

$\square$ early morning stiffness

$\square$ foot cramps

$\square$ end-of-dose deterioration

$\square$ on-off phenomenon

\section{Dopamine-like action ${ }^{3}$}

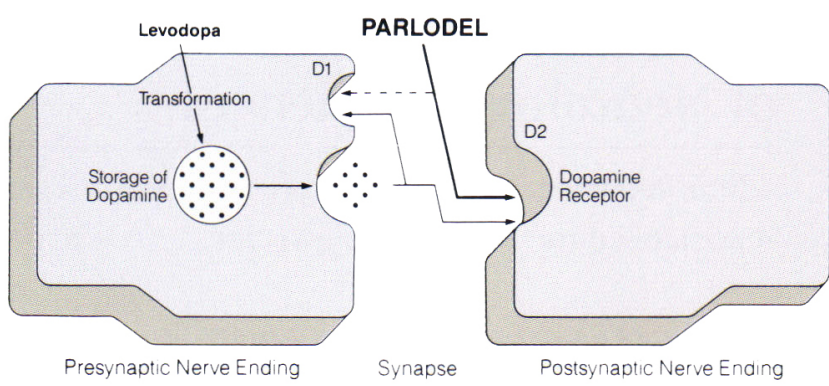

Help protect the quality of life for your Parkinson patients over the long term with Parlodel. 2,4 Added to levodopa, it may allow lower doses for fewer longterm levodopa side effects ${ }^{4,5,6}$, and prolong the total useful period of active treatment. ${ }^{1}$

$\square$ Primary effect is directly on postsynaptic receptors. ${ }^{3}$

$\square$ Does not require transformation for its dopaminomimetic effect. ${ }^{3}$

$\square$ Combined therapy with levodopa often leads to significantly improved control. $^{9}$

May permit lower levodopa doses., ${ }^{4,5}$

$\square$ Longer plasma half-life (Parlodel 2-8 hours vs. levodopa 1 hour). ${ }^{9}$

$\square$ Mainly type D2 dopamine receptor agonist activity.

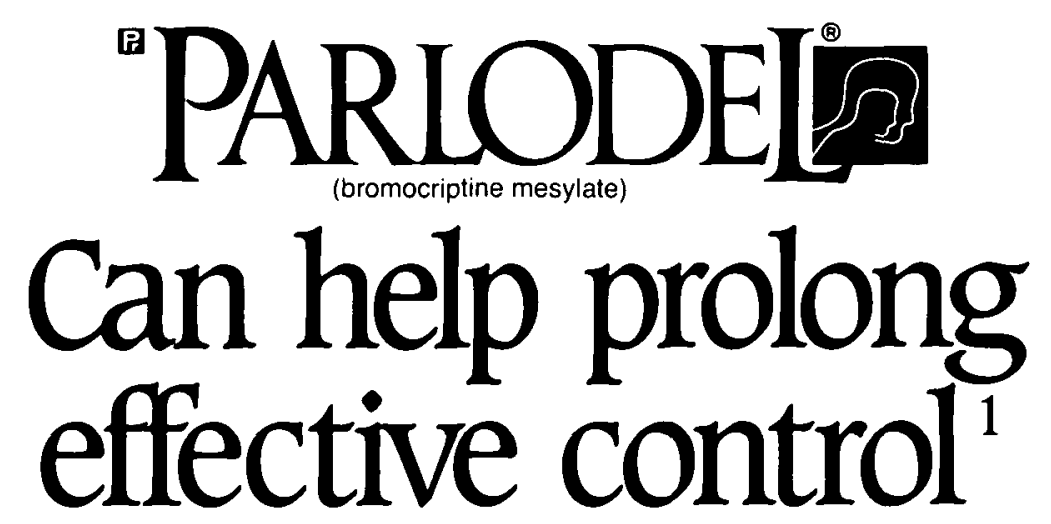




\section{Add Parlodel for improved quality of life $\mathrm{f}^{4,7}$}

In combination with levodopa, Parlodel may provide effective long-term control of Parkinson symptoms ${ }^{9}$, with decreased functional disability and increased mobility. ${ }^{2}$

\section{Mean improvement chart}

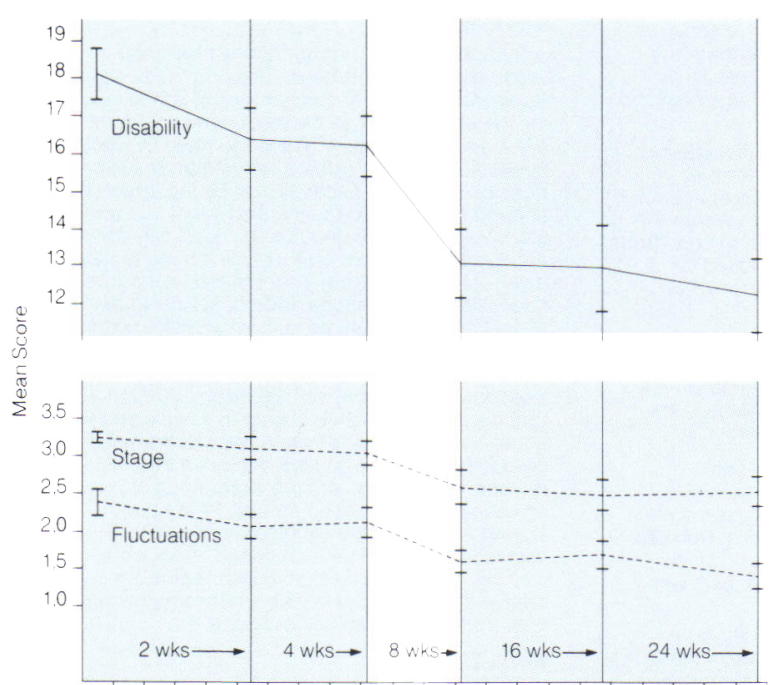

In a recently reported Canadian multicentre trial of Parlodel as adjunctive therapy ${ }^{4}$

43\% improvement in end-of-dose deterioration in a majority of patients

$\square 33 \%$ reduction in total disability scores

$\square$ low mean daily doses of Parlodel $12 \mathrm{mg}$ (8 weeks) $22 \mathrm{mg}$ (24 weeks)

$15 \%$ average decrease of levodopa

\section{Add Parlodel}

When levodopa no longer provides sufficient control, adding Parlodel is an alternative to increasing the dose of levodopa. Likewise, Parlodel can be an important adjunct when prominent dyskinesia appear. Parlodel - a new era in the treatment of Parkinson's disease.

\section{"PARLODE[} for added control 


\section{ADD \\ " For added control}

ACTIONS Parlodel (bromocriptine mesylate) is a dopaminomimetic ergot derivate with $\mathrm{D}_{2}$ type dopamine receptor agonist activity, and has also $D_{1}$ dopamine receptor antagonist properties. The dopaminomimetic activity of bromocriptine in the striatum is considered responsible for the clinical benefits seen in selected patients with Parkinson's Disease, when low doses of the drug are gradually added to levodopa therapy in patients on long-term treatment who develop late side effects of levodopa or no longer respond to the medication. Excessive dopaminomimetic drive may, however, provoke psychotic and other adverse reactions.

The extreme variability in G.I. tract absorption, and the extensive and individually variable first-pass metabolism is responsible for the broad variability in plasma concentrations of bromocriptine and, in part, for the variability in dose response.

INDICATIONS* Parkinson's Disease: Parlodel (bromocriptine mesylate) has been found to be clinically useful as an adjunct to levodopa (usually with a decarboxylase inhibitor), in the symptomatic management selected patients with Parkinson's Disease who experience prominent dyskinesia or wearing off reactions on long-term levodopa therapy.

Patients on long-term treatment who are beginning to deteriorate on levodopa therapy may be controlled by reducing the dose of levodopa and adjusting the frequency and schedule of drug administration. Patients maintained on optimal dosages of levodopa who still experience prominent dyskinesia and/or end-of-dose failure, may benefit from the concomitant use of Parlodel, by decreasing the occurrence and/or severity of these manifestations. Since rapid escalation of bromocriptine doses causes severe adverse reactions, it is recommended to combine a slow increase of Parlodel, usually with a concomitant, gradual and limited reduction of levodopa dosage. Continued efficacy ed reduction of levodopa dosage. Continued efficacy established and there is some evidence that its efficacy established and there is some evidence that its efficacy tends to wane. Evidence available indicates that there is
no consistent benefit from bromocriptine in patients who have not responded previously to levodopa, and studies have shown significantly more adverse reactions in bromocriptine treated patients than in patients treated with levodopa. Parlodel is not recommended in the treatment of newly diagnosed patients or as the sole medication in Parkinson's Disease.

CONTRAINDICATIONS Other than sensitivity to ergot alkaloids, no absolute contraindications to treatment with Parlodel (bromocriptine mesylate) are known. For procedure during pregnancy see "Use in Pregnancy" under Precautions.

WARNINGS Long-term treatment (6-36 months) with Parlodel in doses of 20 to $100 \mathrm{mg} /$ day has been associated with pulmonary infiltrates, pleural effusion and thickening of the pleura in a few patients. Where Parlodel was discontinued, these changes slowly reverted to normal.

PRECAUTIONS Parlodel (bromocriptine mesylate) may cause hypotension, primarily postural; periodic monitoring of the blood pressure, particularly during the first days of therapy, is advisable. In some patients dizzi ness (vertigo) may occur with Parlodel; patients should therefore be cautioned against activities requiring rapid and precise responses such as driving an automobile or operating dangerous machinery until their response or operating dangerous

Care should be exercised when administering Parlodel concomitantly with phenothiazines or antihypertensive agents. Due to drug interaction at the receptor site, dosage should be adjusted accordingly.

Alcohol should be avoided during treatment with Parlodel. In some patients, the concomitant use of Parlodel and alcohol has given rise to alcohol intolerance and an increase in the severity and incidence of Parlodel's possible adverse reactions.

Parlodel should always be taken with food. In cases where severe adverse effects, such as nausea, vomiting, vertigo or headaches are severe or persisting, the therapeutic dosage of Parlodel should be reduced to one-half tablet daily $(1.25 \mathrm{mg})$ and increased gradually

As with all medication, Parlodel should be kept safely out of the reach of children.

Use in Pregnancy If the patient wishes to become pregnant, Parlodel (bromocriptine mesylate) should be stopped as soon as possible after conception is sus. pected. In this event immunological confirmation should be done immediately. When pregnancy is confirmed, Parlodel, like all other drugs, should be discontinued unless, in the opinion of the treating physician, the possible benefit to the patient outweighs the potential risk to the fetus.
In human studies with Parlodel (reviewed by Turkalj, I.), there were 1410 reported pregnancies, which yielded 1236 live and 5 stillborn infants from women who took cy. Among the 1241 infants, 43 cases ( 31 minor and 12 major) of congenital anomalies were reported. The incidence $(3.46 \%)$ and type of congenital maltormations and the incidence of spontaneous abortions $(11.13 \%)$ in this group of pregnancies does not exceed that generally reported for such occurrences in the population at large.

\section{Gynecological Supervision All women patients} receiving Parlodel continuously for six months or more should have a gynecological examination before therapy, yearly if still menstruating, and six-monthly if menopausal. The examination should include cervical and, if possible, endometrial cytology. Post-menopausal and, if possible, endometrial cytology. Post-menopau women on estrogen therapy should be excluded from
Parlodel therapy at the discretion of the physican because estrogen induced uterine bleeding may mask the presence of pathological lesions.

A lifetime rat study revealed that some animals developed uterine tumors and endometrial carcinoma thought to be due to a state of induced estrogen dominance. However, clinical experience in women with a variety of hyperprolactinemic|and other conditions, treated with Parlodel for months or years, failed to demonstrate abnormal trends in hormonal levels or in endometrial cytology.

Normoprolactinemic women treated with Parlodel should be given the lowest effective dose necessary to relieve their symptoms, in order to avoid the possibility a consequent impairment of lutea! function.

\section{Use in Parkinson's Disease: Use of Parlodel} (bromocriptine mesylate), particularly in high doses, may be associated with mental confusion and mental disturbances. Since patients with Parkinson's Disease may manifest varying degrees of dementia, caution should be exercised when treating such patients with Parlodel.

Parlodel administered alone or concomitantly with levodopa may cause visual or auditory hallucinations. These usually resolve with dosage reduction, but discontinuation of Parlodel may be required in some cases. Rarely, after high doses, have hallucinations persisted for several weeks following discontinuation of Parlodel. Caution should be exercised when administering Parlodel to patients with a history of myocardial infarction, particularly if they have a residual atrial, infarction, particularly if they have
nodal or ventricular arrhythmia.

Symptomatic hypotension can occur and, therefore, caution should be exercised when administering Parlodel, particularly in patients receiving antihypertensive medication. Periodic evaluation of hepatic. hematopoietic, cardiovascular and renal function is recommended.

Drug Interactions: The concomitant use of erythromycin may increase bromocriptine plasma levels.

AOVERSE REACTIONS The most frequently observed adverse reactions are nausea, vomiting headache and gastrointestinal side effects such as abdominal pain, diarrhea and constipation. All these effects may be minimized or even prevented by giving small initial doses of bromocriptine and by taking it with food.

Postural hypotension which can, on rare occasions, lead to fainting and "shock-like" syndromes have been reported in sensitive patients. This is most likely to occur during the first few days of Parlodel treatment.

When bromocriptine is added to levodopa therapy, the incidence of adverse reactions may increase. The most common newly appearing adverse reactions in combination therapy were: nausea, abnormal involuntary movements, hallucinations, confusion, "on-off" phenomenon, dizziness, drowsiness, faintness, fainting, vomiting, asthenia, abdominal discomfort, visual disvomiting, asthenia, abdominal discomfor, visual disshortness of breath, constipation and vertigo.

Less common adverse reactions include, anorexia, anxiety, blepharospasm, dry mouth, dysphagia, edema of the feet and ankles, erythromelalgia, epileptiform seizures, fatigue, headache, lethargia, mottling of skin, nasal stuffiness, nervousness, nightmares, parethesia, skin rash, urinary frequency, urinary incontinence, urinary retention and rarely signs of symptoms of ergotism nary retention and rarely signs of symptoms of ergotism such as tingling of fingers, cold feet, numbness, muscl
cramps of feet and legs or exacerbation of Raynaud's cramps of

Abnormalities in laboratory tests may include elevation of blood urea nitrogen, SGOT, SGPT, GGPT, CPK alkaline phosphatase and uric acid, which are usually transient and not of clinical significance.
The occurrence of adverse reactions may be lessened by temporarily reducing dosage to one-half tablet two
or three times daily.

\section{SYMPTOMS AND TREATMENT OF OVERDOSE}

There have been several reports of acute overdosage with Parlodel (bromocriptine mesylate) in children an adults. No life threatening reactions have occurred. Symptoms reported included nausea, vomiting, dizzi-
ness, drowsiness, hypotension, sweating and hallucinations. Management is largely symptomatic; the cardiovascular system should be monitored. Metoclopramide can be used to antagonize the emesis and hallucinations in patients who have taken high doses.

\section{DOSAGE AND ADMINISTRATION Parlodel} (bromocriptine mesylate) should always be taken with tood.

Although Parlodel (bromocriptine mesylate) has been found clinically useful in decreasing the severity and frequency of "on-off" fluctuations of late levodopa thera py, the decision to use bromocriptine as adjunctive treatment and the selection of dosage must be individualized in each case. A low dose is recommended. The initial dose of Parlodel is one half of a $2.5 \mathrm{mg}$ tablet $(1.25 \mathrm{mg})$ at bedtime with food to establish initial tolerance. There after, the recommended dosage is $2.5 \mathrm{mg}$ daily in two divided doses, with meals, (half a $2.5 \mathrm{mg}$ tablet twice daily). The dosage may be increased very gradually, if necessary, by adding an additional $2.5 \mathrm{mg}$ per day, once every 2 to 4 weeks, to be taken always in divided doses with meals. Increments should usually never exceed $2.5 \mathrm{mg}$. Clinical assessments are recommended at two week intervals or less during dosage titration, to ensure week intervals or less during dosage titration, to ensure that the lowest effective dosage is not exceeded. The
usual dosage range is from a few milligrams to $40 \mathrm{mg}$ usual dosage range is from a few milligrams to $40 \mathrm{mg}$
daily in two or three divided doses with meals. The daily in two or three divided doses with meals. The
median dose varies with the experience of individual investigators, but can be around $10 \mathrm{mg}$ daily or higher. During initial titration it is recommended that the dosag of levodopa should be maintained, if possible. Subsequently, it might be desirable to combine a slow increase of bromocriptine with a concomitant, limited and gradual reduction of levodopa.

\section{AVAILABILITY}

1. TABLETS each containing $2.5 \mathrm{mg}$ bromocriptine, as mesylate, available in bottles of 100 .

Scored $7 \mathrm{~mm}$, round compressed white tablets with " $X C$ " on one side and "PARLODEL" on the reverse.

2. CAPSULES each containing $5 \mathrm{mg}$ bromocriptine, as mesylate, available in bottles of 100. Caramel and white size 3 hard shell capsules with "PARLODEL" on one side and " $5 \mathrm{mg}$ " on the other.

\section{REFERENCES:}

1. Levodopa: Long-term impact on Parkinson's disease. (editorial) Br. Med. J. 1981; 282:417-418.

2. Lieberman A.N. et al. Can. J. Neurol. Sci. 1984 11(1): (Suppl.): 233-237.

3. Calne D.B. et al. Can. J. Neurol. Sci. 1984; 11(1): (Suppl.): 221-224 4. Grimes J.D. et al. Can. J. Neurol. Sci. 1984; (4): $452-456$. 5. Grimes J.D. Can. J. Neurol. Sci. 1984; 11(1): 225-228. 6. Rascol A. et al. Can. J. Neurol. Sci. 1984; 11(1); 229-231. 7. Ludin H.P. et al. Lancet 1978; 2: 578-579.

8. Marsden C.D. and Parkes J.D. Lancet 1977; 1 345-349.

9. Godwin-Austen R.B. Res. Clin. Forums 1981; 3(2): 19-23.

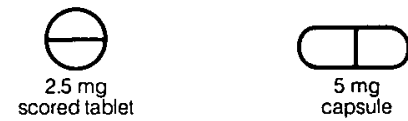
CCPP

"For information on other approved indications, please consult the Parlodel product monograph, available to physicians and pharmacists on request.

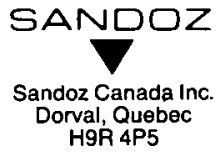




\section{Information for Authors}

The Canadian Journal of Neurological Sciences publishes original articles in the clinical and basic neurosciences. Manuscripts are considered for publication with the understanding that, except for identified review articles, they have not been published elsewhere except in abstract form and are not under simultaneous consideration by another publication. Manuscripts should be submitted to:

The Editor

Canadian Journal of Neurological Sciences

Faculty of Medicine,

University of Calgary

3330 Hospital Drive N.W.

Calgary, Alberta T2N 4N1

Manuscripts and all illustrations should be submitted in triplicate. Papers will be accepted in English or French. All papers should be accompanied by an abstract or a résumé of approximately 150 words on a separate page, preferably in both languages, although the Journal will provide the translation if requested. All manuscripts should be double spaced throughout, including references and legends for illustrations. Margins of at least 25 $\mathrm{mm}$ should be left on all sides.

For detailed instructions regarding style and layout, authors should refer to "Uniform requirements for manuscripts submitted to biomedical journals". Copies of this document may be obtained by writing to the Journal office, but the main points will be summarized here. Articles should be subdivided under conventional headings of "introduction", "methods and materials", "results" and "discussion" but other headings and subheadings will be considered if more suitable for a particular manuscript. A title page should identify the title of the article, authors, name of institution(s) from which the work originated, and the address and telephone number of the author to whom communications should be addressed. Pages of text should be numbered consecutively. Acknowledgements, including recognition of financial support, should be typed on a separate page at the end of the text.

References are to be numbered in the order of citation in the text. Those cited only in tables or in legends for illustrations are numbered in accordance with a sequence established by the first identification in the text of a particular table or illustration. Titles of journals should be abbreviated according to the style used in Index Medicus. References should be complete including the names of the first three authors followed by "et al" if there are more than three authors, full title, year of publication, volume number, and inclusive pagination for journal articles. Book or chapter references should also include the place of publication and name of the publisher. Examples of correct forms of references follow:

\section{Journals}

Poirier LI, Filion M, Larochelle L, et al. Physiopathology of experimen-

tal parkinsonism in the monkey. Can J Neurol Sci 1975; 2: 255-263

\section{Chapter in a book}

McGeer PL, McGeer EG. Amino acid neurotransmitters. In: Siegel G],

Albers RW, Agranoff BW, Katzman R, eds. Basic Neurochemistry.

Boston: Little, Brown \& Co, 1981: 233-254

Illustrations should be high quality glossy black-and-white photographic prints, preferably $127 \times 173 \mathrm{~mm}\left(5 \times 7^{\prime \prime}\right)$. Original artwork and radiographs should not be submitted. The additional cost of colour illustration must be borne by the author; quotations are available upon request from the Journal office. All figures should be identified on the back with the author's name and figure number. Letters and arrows applied to the figures to identify particular findings should be professional appliques suitable for publication. Photomicrographs should include a calibration bar with the scale indicated on the figure or in the legend. Legends for illustrations should be typed on a separate page from the illustrations themselves.

Tables should each be on a separate page and be identified with the title or heading. Particular care should be taken in the preparation of tables to ensure that the data are presented in the most clear and precise format. Each column should have a short or abbreviated heading. Place explanatory matter in footnotes, not in the heading. Do not submit tables as photographs.

The SI system (système international d'unités) should be used in reporting all laboratory data, even if originally reported in another system. Temperatures are reported in degrees Celsius. Other measurements should be reported in the metric system. English language text may use either British or American spelling, but should be consistent throughout.

Review articles on selected topics also are published by the fournal. These are usually invited, but unsolicited reviews will be considered. It is suggested that authors intending to submit reviews contact the Editor in advance.

Letters to the Editor are welcome. These should be limited to two double-spaced pages and may include one illustration and a maximum of four references.

\section{Information aux Auteurs}

Le Journal Canadien des Sciences Neurologiques publie des articles originaux dans les sciences neurologiques, cliniques et fondamentales. Les manuscrits ne sont considérés pour publication qu'à la condition expresse, à l'exception des articles de revue clairement identifiés comme tel, qu'ils n'aient pas été publiés ailleurs, sauf sous forme de résumé et qu'ils ne soient pas sous considération simultanée par un autre journal. Les manuscrits doivent être soumis à:

L'Editeur

Journal Canadien des Sciences Neurologiques,

Faculté de Médecine,

Université de Calgary,

33.30 Hospital Drive, N.W.

Calgary, Alberta T2N $4 \mathrm{N1}$

Les manuscrits et toutes les illustrations doivent être soumis en triplicata. Les articles seront acceptés en français ou en anglais. Tous les articles doivent être accompagnés d'un résumé d'environ 150 mols, sur page séparée, préférablement dans les deux langues, quoique le Journal puisse fournir cette traduction sur requête. Les manuscrits doivent être dactylographiés complètement à double interligne y compris les références et les légendes pour illustrations. Des marges d'au moins $25 \mathrm{~mm}$ doivent être laissées de tous les côtés

Pour les conseils plus détaillés sur le style et la présentation du texte, les auteurs doivent se référer au texte intitulé "Règlements uniformes pour les manuscrits soumis aux journaux biomédicaux". On peut obtenir une copie de ce document en écrivant au bureau du fournal, mais en voici les principaux points: Les articles doivent être présentés selon le plan habituel: "Introduction", "Matériel et méthodes", "Résultats" et "Discussion", mais il est possible d'employer d'autres titres ou sous-titres si nécessaire pour un manuscrit en particulier. Sur une page titre séparée on doit identifier le titre de l'article, les auteurs, les institutions d'où origine le travail, ainsi que l'adresse et le numéro de téléphone de l'auteur à qui devront être adressées les communications. Les remerciements, incluant ceux pour l'appui financier, doivent être dactylographiés sur page séparée à la fin du texte. Les références doivent être numérotées dans l'ordre où elles sont citées dans le texte. Celles qui sont citées seulement dans les tableaux ou légendes d'illustrations sont numérotées selon la séquence établie par la première identification dans le texte de ces tableaux ou illustrations particulières. Les titres des Journaux doivent être abrégés selon le style utilisé dans Index Medicus. Les références doivent être complètes, incluant le nom des trois premiers auteurs suivis de "et al", s'il y a plus de trois auteurs, le titre complet, l'année de publication, le numéro du volume et les premières et dernières pages de l'article. Les références aux livres et chapitres de livres doivent aussi inclure le lieu de la publication et le nom de la maison d'édition. Les exemples corrects suivants peuvent être utilisés:

\section{Journaux}

Poirier LI, Filion M, Larochelle $L$, et al. Physiopathology of experimental parkinsonism in the monkey. Can I Neurol Sci 1975; 2: 255-263

\section{Chapitre de livre}

McGeer PL, McGeer EG, Amino acid neurotransmitters. In: Siegel GJ, Albers RW, Agranoff BW, Katzman R, eds. Basic Neurochemistry. Boston: Little, Brown \& Co, 1981: 233-254

Les illustrations doivent être sur papier brillant de haute qualité et imprimés en blanc et noir, préférablement $127 \times 173 \mathrm{~mm}\left(5 \times 7^{\prime \prime}\right)$. Les illustrations et photographies originales ne doivent pas être soumises. Le coût supplémentaire des illustrations en couleur revient entièrement à l'auteur; les coûts détaillés peuvent être obtenus directement au bureau du Journal. Il faut identifier toutes illustrations en inscrivant au dos le nom de l'auteur et le numéro. Toutes lettres ou flèches appliquées aux illustrations pour identifier un aspect particulier doivent ètre de qualité professionnelle. Les photomicrographies doivent inclure une barre de calibration dont l'échelle est mentionée dans la légende. Les légendes des illustrations doivent être dactylographiées sur une page séparée de celles-ci.

Les tableaux doivent être sur des pages séparées et être identifiés avec titre. On doit prendre un soin particulier dans la préparation de ces tableaux afin d'assurer que les données soient présentées avec le format le plus clair et le plus précis possible. Chaque colonne doit avoir un court titre. Les explications doivent être placées en dessous du tableau et non en sous-titre. Un tableau ne doit pas être soumis sous forme de photographie.

On doit employer le système international d'unités (SI) pour toutes données de laboratoire, même si celles-ci sont originellement présentées dans un autre système. Les températures doivent être citées en degrés Celcius. Les autres données doivent utiliser le système métrique. Les textes en anglais peuvent utiliser l'orthographe anglais ou américain, mais cet usage doit être constant.

Le Journal publie également des articles de revue sur des sujets sélectionnées. Ces articles sont généralement sur invitation, mais, à l'occasion, une revue non sollicitée peut être acceptée. Il serait préférable que les auteurs ayant l'intention de soumettre une telle revue contactent d'abord I'Editeur.

Nous accueillons les lettres à l'Editeur. Celles-ci doivent se limiter à deux pages, double interligne et peuvent contenir une seule illustration et ne citer qu'un maximum de quatre références. 


\section{HOLD ITI}
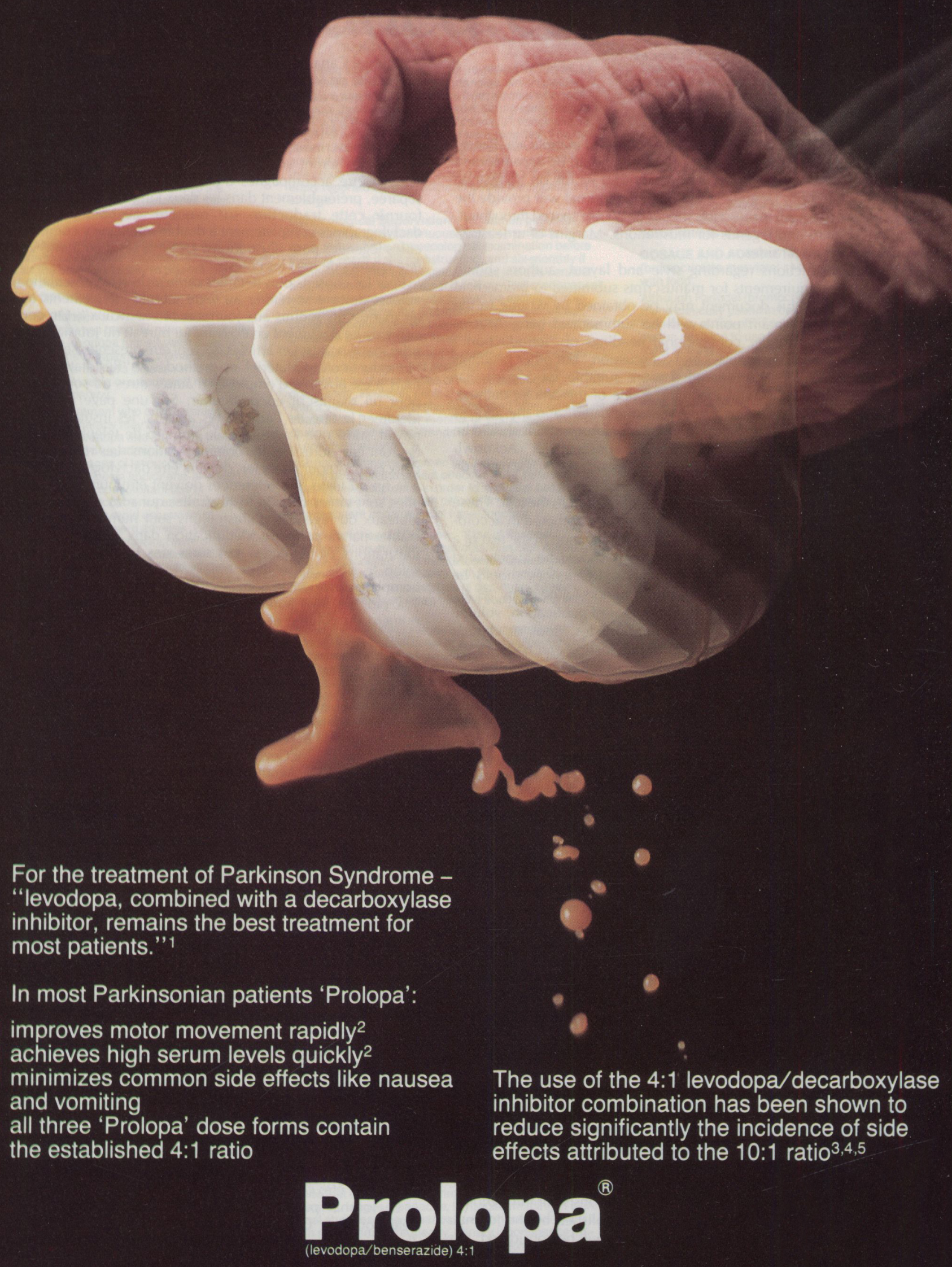

Helps return the simple pleasures of living. 



\section{Evomatic $^{\circledR} 4000 / 8000$}

\section{- for evoked potentials in:}

\section{Neurophysiology}

Evaluation of Tumors, Traumas, Degenerative and Vascular diseases.

\section{Psychology \& Psychiatry}

The study of Language, Performance, Senile Dementia and Psychosis.

\section{Otolaryngology}

Early detection of Tumors, Lesions of the Cochlear Organ and the Brain Stem.

\section{Ophthalmology}

Separating Retinal Lesions from Opacities in the Refractory Media.

\section{Surgery}

Intraoperative monitoring during surgery of Spine, Heart, Eye and Posterior Fossa.

\section{Pediatrics}

Assessment of Hearing and Visual Acuity.

\section{Research}

In Neurophysiology, Drug Industry, Psychology, Space Science, etc.

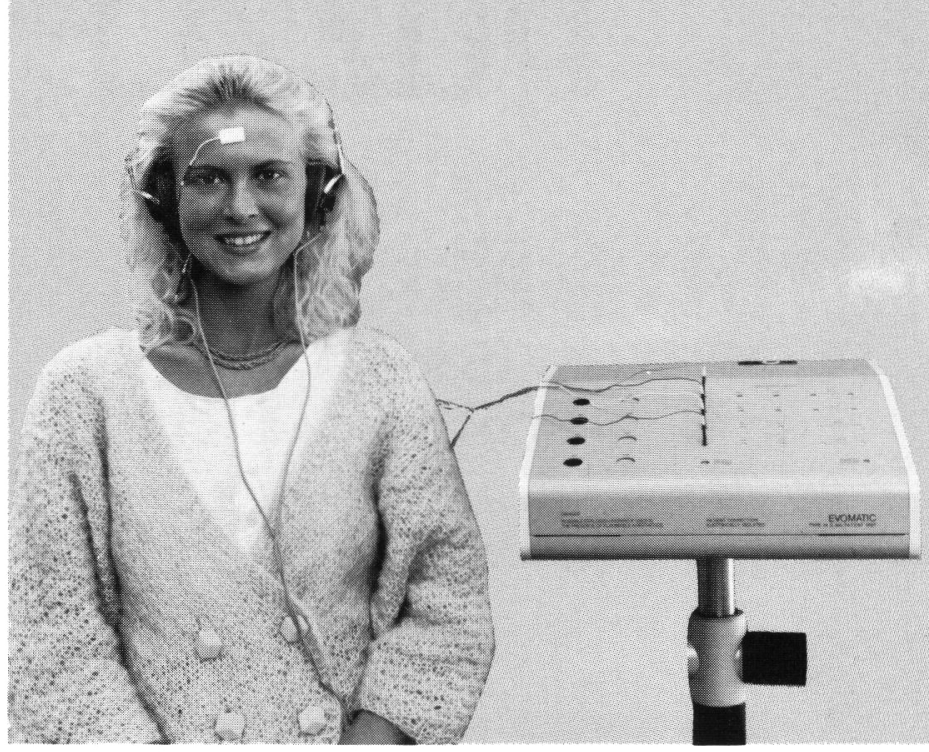

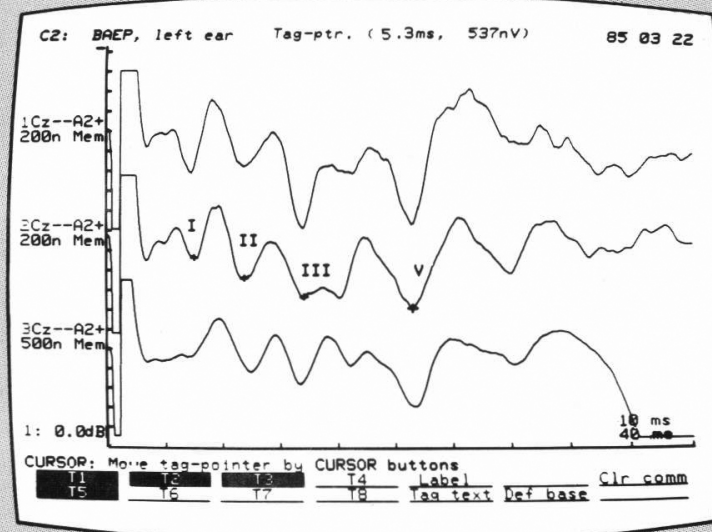

Auditory

Objective Hearing Level $50 \mathrm{~dB}$ 


\section{PTegretol ${ }^{\circledR}$ Chewtabs $^{\text {TM }}$ \\ (carbamazepine \\ chewable tablets) \\ $100 \mathrm{mg}$ and $200 \mathrm{mg}$}

\section{For Symptomatic Relief of \\ Trigeminal Neuralgia \\ Anticonvulsant}

\section{Action:}

TEGRETOL (carbamazepine) has anticonvulsant properties which have been found useful in the treatment of psychomotor and other partial epilepsies, when administered in conjunction with other anticonvulsant drugs to prevent the possible generalization of the epileptic discharge. A mild psychotropic effect has been observed in some patients, which seems related to the effect of the carbamazepine in psychomotor or temporal lobe epilepsy. TEGRETOL relieves or diminishes the pain associated with trigeminal neuralgia often within 24 to 48 hours. Indications and Clinical Use

A. Trigeminal Neuraigia

For the symptomatic relief of pain of trigeminal neuralgia only during periods of exacerbation of true or primary trigeminal neuralgia (tic douloureux). Do not use preventively during periods of remission. In some patients, TEGRETOL has relieved glossopharyngeal neuralgia.

For patients who fail to respond to TEGRETOL, or who are sensitive to the drug, recourse to other accepted measures must be considered.

TEGRETOL is not a simple analgesic and should not be used to relieve trivial facial pains or headaches.

B. TEGRETOL has been found useful:

1) in the management of psychomotor (tempora lobe) epilepsy, and,

2) as an adjunct, in some patients with secondary or partial epilepsy with complex symptomatology or secondarily generalized seizures, when administered in combination with other antiepileptic medication

3) as an alternative medication in patients with generalized tonic-clonic seizures who are experiencing marked side effects or fail to respond to other anticonvulsant drugs.

TEGRETOL is ineffective in controlling petit mal, minor motor, myoclonic and predominantly unilateral seizures, and does not prevent the generalization of epileptic discharge.

\section{Warnings}

Although reported infrequently, serious adverse effects have been observed during the use of TEGRETOL.

Agranulocytosis and aplastic anemia have occurred in a few instances with a fatal outcome. Leucopenia, thrombocytopenia and hepatocellular and cholestatic jaundice have also been reported. It is, therefore, important that TEGRETOL should be used carefully and close clinical and frequent laboratory supervision should be maintained throughout treatment in order to detect as early as possible signs and symptoms of a possible blood dyscrasia. Long-term toxicity studies in rats indicated a potential carcinogenic risk. Therefore, the possible risk of drug use must be weighed against the potential benefits before prescribing carbamazepine to individual patients.

\section{Contraindications}

Hepatic disease, serious blood disorder, less than 14 days either before or after monoamine oxidase inhibitor (then the dosage of TEGRETOL should be low initially, and increased very gradually), atrioventricular heart block, hypersensitivity to tricyclic compounds, lactation, first trimester of pregnancy.
Usage in Pregnancy

As safety has not been established, TEGRETOL should not be given to women of childbearing potential unless, in the opinion of the physician, the expected benefits to the patient outweigh the possible risk to the foetus.

\section{Precautions}

Monitoring of Haematological and Other Adverse Reactions:

Complete blood studies, including platelet counts, and evaluation of hepatic and renal function and urinalysis should be carried out before treatment is instituted and frequent clinical and laboratory supervision should be maintained throughout treatment. If any signs or symptoms or abnormal laboratory findings suggestive of blood dyscrasia or liver disorder occur, TEGRETOL should be immediately discontinued.

Urinary Retention and Increased Intraocular Pressure: Caution is advised in patients with increased intraocular pressure or urinary retention due to the drug's anticholinergic action.

Occurrence of Behavioural Disorders

TEGRETOL may activate a latent psychosis, or, in elderly patients, produce agitation or confusion. Caution is advised in alcoholics.

Use in Patients with Cardiovascular Disorders: Caution is advised in patients with a history of coronary artery disease, organic heart disease, or congestive ailure An E K G should be performed if a defective conductive system is suspected before administering TEGRETOL, in order to exclude patients with atrioventricular block.

Use in Patients taking Oral Contraceptives:

Women under treatment with TEGRETOL and oral contraceptives, should be advised to use some alternative, non-hormonal method of contraception as the reliability of oral contraceptives may be adversely affected. Driving and Operating Hazardous Machinery:

Warn patients about the possible hazards of operating machinery or driving automobiles as dizziness and drowsiness are possible side effects of TEGRETOL.

\section{Adverse Reactions}

Haematological reactions: Transitory leucopenia, eosinophilia, leucocytosis, thrombocytopenic purpura agranulocytosis, macrocytic anemia and aplastic anemia. In a few instances, deaths have occurred. Hepatic Disturbances: Abnormalities in liver function tests, cholestatic or hepatocellular jaundice. Dermatological Reactions: Skin sensitivity reactions and rashes, erythematous rashes, pruritic eruptions urticaria, photosensitivity, pigmentary changes neurodermatitis and in rare cases Stevens-Johnson syndrome, exfoliative dermatitis, alopecia, diaphoresis, erythema multiforme, erythema nodosum, and aggravation of disseminated lupus erythematosus. Neurological Reactions: Vertigo, dizziness, somnolence, disturbances of coordination, confusion, headache, fatigue, blurred vision, transient diplopia and oculomotor disturbances, speech disturbances, abnormal involuntary movements, increase in motor seizures, peripheral neuritis, paresthesia, depression with agitation, talkativeness, nystagmus, tinnitus, paralysis and other symptoms of cerebral arterial insufficiency.

Cardiovascular Systems: Recurrence of thrombophlebitis, congestive heart failure, aggravation of hypertension, Stokes-Adams in patients with AV block hypotension, syncope and collapse, edema, aggravation of coronary artery disease. Some of these complications (including myocardial infarction and arrhythmia) have been associated with other tricyclic compounds.

Genitourinary Reactions: Urinary frequency, acute urinary retention, oliguria with elevated blood pressure, impotence, elevation of BUN, albuminuria, and glycosuria.

Digestive Tract: Nausea, vomiting, gastric or abdomina discomfort, diarrhoea, anorexia, dryness of the mouth and throat, glossitis and stomatitis

Eyes: There is no conclusive evidence that TEGRETOL produces pathological changes in the cornea, lens or retina. However, it should be recognized that many phenothiazines and related drugs have been shown to cause eye changes. By analogy, periodic eye examinations, including slitlamp fundoscopy and tonometry, are recommended.

Other Reactions: Fever and chills, lymphadenopathy, ching joints and muscles, leg cramps and conjunctivitis.

\section{Symptoms and Treatment of Overdosage}

ymptoms: Dizziness, ataxia, drowsiness, stupor, nausea, vomiting, restlessness, agitation, disorientation: tremor, involuntary movements, opisthotonos, abnormal reflexes (slowed or hyperactive); mydriasis, nystagmus; flushing, cyanosis, urinary retention, hypotension, hypertension, coma. The EEG may show dysrhythmias The laboratory findings have included leukocytosis, reduced leukocyte count, glycosuria and acetonuria. Treatment: No known specific antidote. Induce emesis. Perform gastric lavage. Watch vital signs and administer symptomatic treatment as required. Hyperirritability may be controlled by the administration of parenteral barbiturates. Barbiturates should not be used if monoamine oxidase inhibitors have also been taken by the patient, either in overdosage or in recent therapy (within two weeks). Barbiturates may induce respiratory depression, particularly in children, therefore, have equipment available for artificial ventilation and resuscitation. Paraldehyde may be used to counteract muscular hypertonus without producing respiratory depression. Treat shock (circulatory collapse) with supportive measures, including intravenous fluids oxygen, and corticosteroids. Electrocardiogram should be monitored, particularly in children, to detect any cardiac arrhythmias or conduction defects.

\section{Dosage and Administration}

Use in Epilepsy (see Indications): A low initial daily dosage with a gradual increase in dosage is advised. Dosage should be adjusted to the needs of the individual patient.

Adults and Children over 12 years of age: Initially: 100 to $200 \mathrm{mg}$ once or twice a day. The initial dosage is progressively increased, until the best response is obtained, up $10600 \mathrm{mg}$ daily. Usual Daily Dosage: $600 \mathrm{mg}$, however up to 800 to $1000 \mathrm{mg}$ have been used or short periods. As soon as disappearance of seizures has been obtained and maintained, dosage should be reduced very gradually until a minimum effective dose is reached.

Children 6-12 Years of Age: Initially, $100 \mathrm{mg}$ in divided doses on the first day. Increase gradually by adding 100 mg per day until the best response is obtained. Dosage should generally not exceed $1000 \mathrm{mg}$ daily. As soon as disappearance of seizures has been obtained and maintained, dosage should be reduced very gradually until a minimum effective dose is reached.

Use in trigeminal neuralgia: Initial daily dosage: $100 \mathrm{mg}$ twice daily may be increased by $200 \mathrm{mg}$ per day until relief of pain is obtained. Usual dosage: 200 to $800 \mathrm{mg}$ daily. Up to $1200 \mathrm{mg}$ daily may be necessary. As soon as relief of pain has been obtained and maintained, progressive reduction in dosage should be attempted until a minimum effective dosage is reached. Because trigeminal neuralgia is characterized by periods of remission, attempts should be made to reduce or discontinue the use of TEGRETOL at intervals of not more than 3 months, depending upon the individual clinical course.

Prophylactic use in trigeminal neuralgia is not recommended.

Administer in two or three divided doses daily, with meals whenever possible.

Dosage Forms

TEGRETOL ${ }^{\circledR}$ tablets $200 \mathrm{mg}$ : Each white, round, flat, bevelled-edge double-scored tablet engraved GEIGY on one side contains $200 \mathrm{mg}$ carbamazepine.

TEGRETOL ${ }^{\circ}$ Chewtabs ${ }^{\text {tM }} 100 \mathrm{mg}$ : Pale pink, round, flat, bevel-edged tablets with distinct red spots. GEIGY engraved on one side and MR on the other. Fully bisected between the $M$ and $R$. Each chewable tablet contains $100 \mathrm{mg}$ carbamazepine.

TEGRETOL ${ }^{\circ}$ Chewtabs ${ }^{\text {tm }} 200 \mathrm{mg}$ : Pale pink, oval biconvex tablets with distinct red spots. GEIGY engraved on one side and PU on the other. Fully bisected between the $P$ and $U$. Each chewable tablet contains $200 \mathrm{mg}$ carbamazepine.

Availability

TEGRETOLO tablets $200 \mathrm{mg}$ : Bottles of 100 and 500 tablets. Protect from heat and humidity. TEGRETOL Chewtabs $^{\mathrm{TM}} 100 \mathrm{mg}$ : Bottles of 100. Protect from heat and humidity.

*TEGRETOL ${ }^{\odot}$ Chewtabs $^{\top *} 200 \mathrm{mg}$ : Bottles of 100 . Protect from heat and humidity. (Available September 1985.) Full information available on request.

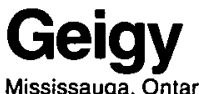

LSN 2W5 


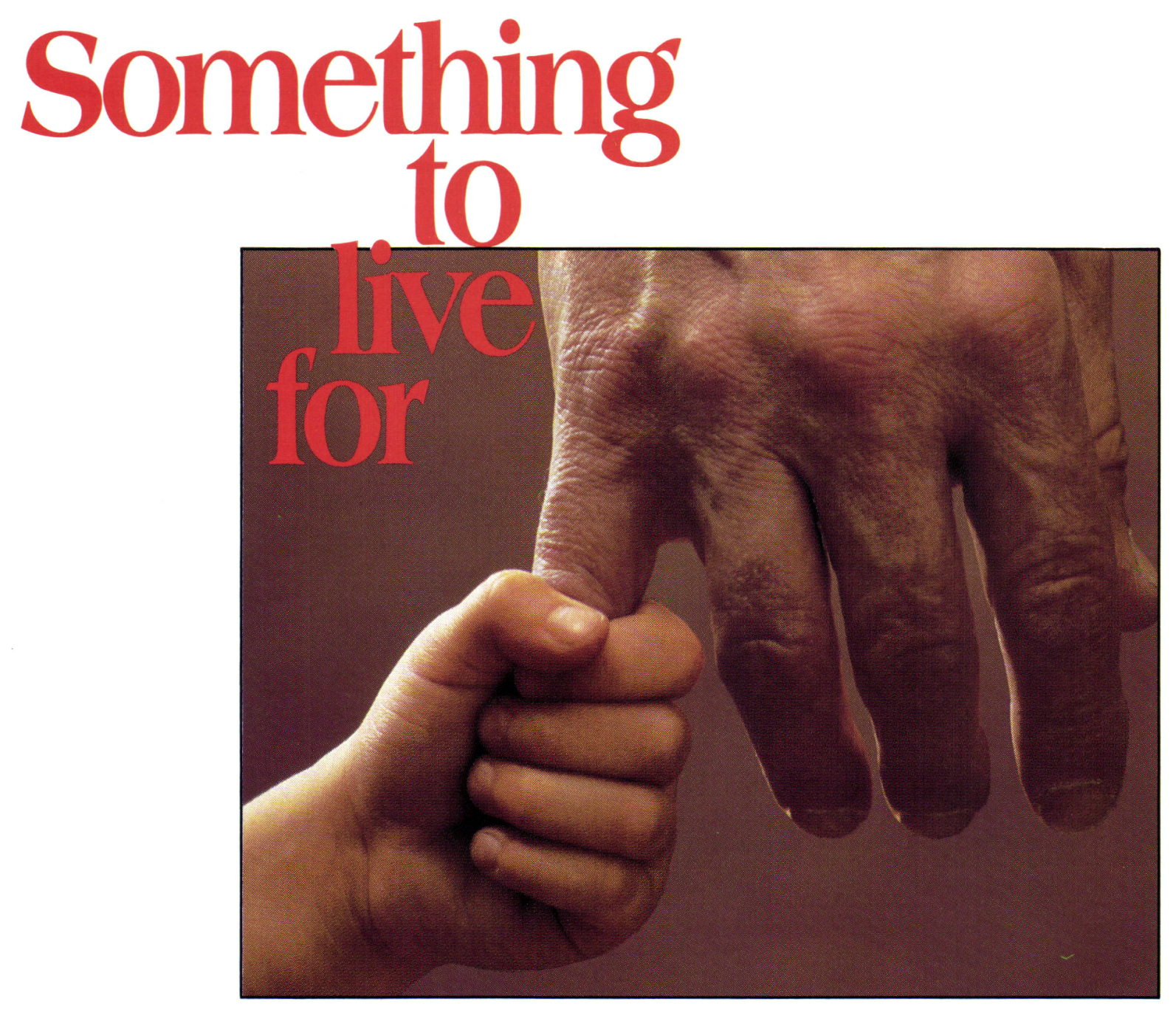

Parkinson's syndrome is an insidious assault on the lifestyles of more than 58,000 Canadians.

For these individuals, daily, routine habits like knotting a tie, or pinning the hair, are often impossible tasks.

Symmetrel ${ }^{\circledR}$ can help many of these patients gain a better hold on their daily lives, and helps you to control the syndrome.
As initial, or adjunctive therapy, Symmetrel $^{\circledR}$ for Parkinson's syndrome offers:

- few significant side effects, even after long-term use. ${ }^{1}$

- noticeable benefits within 24 hours of start-up dose.

- easy usage with levodopa and anticholinergics.'

- simple dosage regimen; simple titration.

\section{STMMIEIRED: \\ can help in Parkinson's Disease}

For brief prescribing information see page xvi

Du Pont Pharmaceuticals Mississauga, Ontario
L5M 2.J4

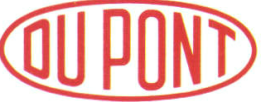
CANADA

$(\mathrm{x})$ 


\section{NOT ALL ELECTRODIAGNOSTIC SYSTEMS ARE CREATED EQUAL Some are created by Nicolet.}

$$
1974
$$

The Nicolet CA 1000 was introduced and quickly became the clinical standard.
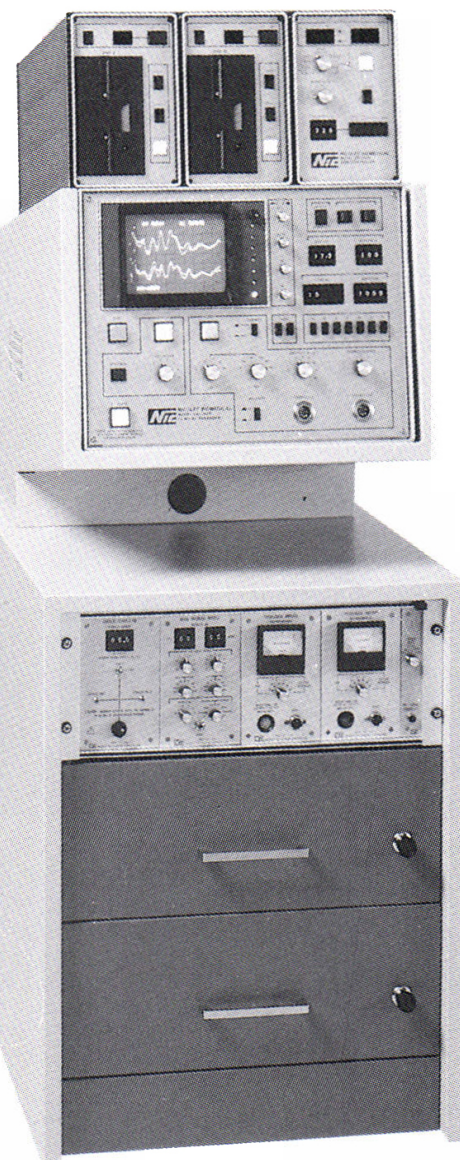

Over 1,500 in use.

1984

The Nicolet Compact Four, the new standard for the clinician who can use comprehensive electrodiagnostic testing.

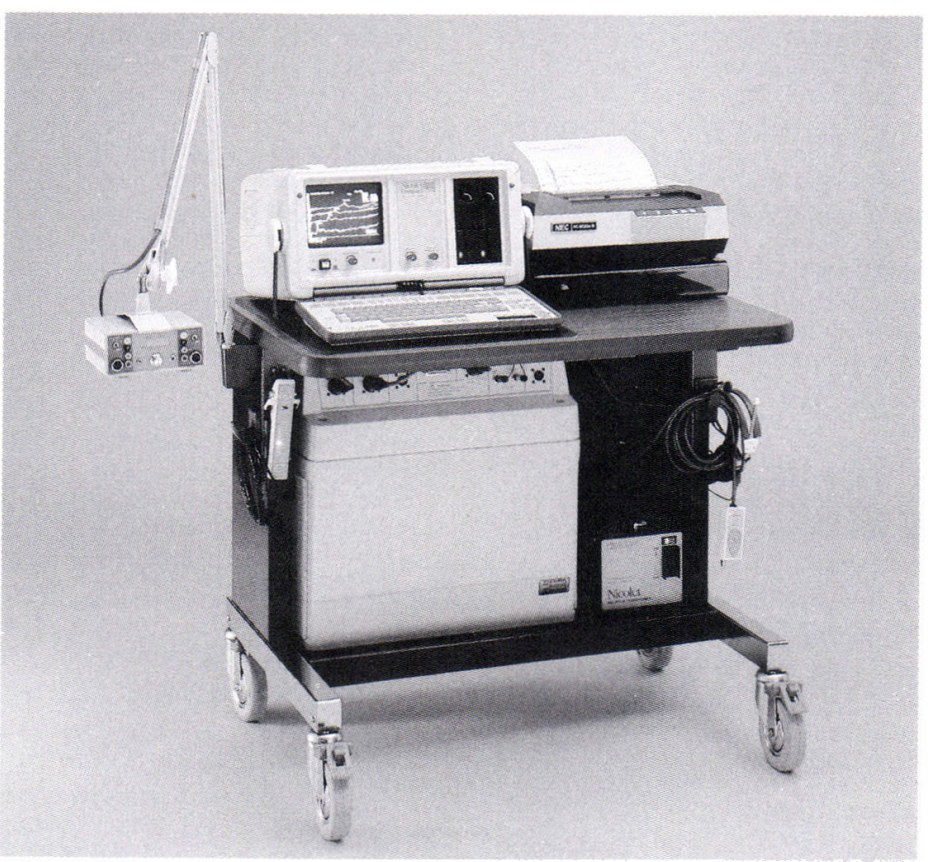

With the Nicolet Compact Four you can do:

$\square$ Auditory evoked potentials $\square$ Nerve conduction velocities (AEP)

$\square$ Visual evoked potentials $\square$ Electroretinography (ERG) (VEP)

$\square$ Somatosensory evoked potentials (SEP)

$\square$ Electromyography (EMG)

$\square$ Electro-oculography (EOG)

$\square$ F-waves

$\square$ H-reflexes

$\square$ Blink reflexes

$\square$ Intraoperative monitoring

This powerful, portable, cost-effective system is ideal for use in private practice, the clinic and/or the hospital.

And, every Nicolet system is backed by:

$\square$ Direct service personnel

$\square$ Training by highly qualified staff $\square$ Applications support by clinically experienced personnel 


\section{Prolopa $^{\oplus}$}

\section{Rx Summan}

Indications

Treatment of Parkinson's syndrome when not druginduced.

\section{Contraindications}

Known hypersensitivity to levodopa or benserazide; in patients in whom sympathomimetic amines are contra indicated; concomitantly with, or within 2 weeks of MAOI administration; uncompensated cardiovascular, endocrine, renal, hepatic, hematologic or pulmonary disease; narrow-angle glaucoma.

Warnings

Discontinue levodopa at least 12 hours before initiating 'Prolopa'. See Dosage section for substitution recom. mendations.

Not indicated in intention tremor, Huntington's chorea or drug-induced Parkinsonism.

Increase dosage gradualiy to avoid CNS side effects (involuntary movements). Observe patients for signs of depression with suicidal tendencies or other serious behavioural changes. Caution in patients with history of psychotic disorders or receiving psychotherapeutic agents. in patients with atrial, nodal or ventricular arrhythmias or history of myocardial infarction initiate treatment cautiously in hospital. Caution in patients with history of melanoma or suspicious undiagnosed skin lesions.

Salety in patients under 18 years has not been established. In women who are or may become pregnant, weigh benefits against possible hazards to mother and fetus. Not recommended for nursing mothers.

Precautions

Monitor cardiovascular, hepatic, hematopoietic and renal function during extended therapy. Caution in patients with history of convulsive disorders. Upper gastrointestinal hemorrhage possible in patients with a history of peptic ulcer.

Normal activity should be resumed gradually to avoid risk of injury.

Monitor intraocular pressure in patients with chronic wide-angle glaucoma. Pupillary dilation and activation of Horner's syndrome have been reported rarely. Exercise caution and monitor blood pressure in patients on antihypertensive medication. 'Prolopa' can be discontinued 12 hours prior to anesthesia. Observe patients on concomitant psychoactive drugs for unusual reactions

Adverse Reactions

Most common are abnormal involuntary movements usually dose dependent, which necessitate dosage reduction. Other serious reactions are periodic oscillations in performance (end of dose akinesia, on-off phenomenon and akinesia paradoxica) after prolonged therapy, psychiatric disturbances (including paranoia, psychosis. depression, dementia, increased libido, euphoria, sedation and stimulation), and cardiovascular effects (including arrhythmias, orthostatic hypotension, hypertension. ECG changes and angina pectoris).

Neurologic, intellectual, gastrointestinal, dermatologic hematologic, musculoskeletal, respiratory, genitourinary and ophthalmologic reactions have also been reported. Consult Product Monograph for complete list.

Dosage

Individualize therapy and titrate in small steps to maximize benefit without dyskinesias. Do not exceed the recommended dosage range.

Initially, one capsule 'Prolopa' $100-25$ once or twice daily, increased carefully by one capsule every third or fourth day (slower in post-encephalitic Parkinsonism) until optimum therapeutic effect obtained without dyskinesias. At upper limits of dosage, increment slowly at 2.4 week intervals. Administer with food

Optimal dosage is usually 4-8 'Prolopa' 100-25 capsules daily, in 4-6 divided doses.

'Prolopa' 200-50 capsules are intended for maintenance therapy once optimal dosage has been determined using 'Prolopa' 100-25 capsules. No patient should receive more than $1000-1200 \mathrm{mg}$ levodopa daily during the first year of treatment. 'Prolopa' 50-12.5 capsules should be used when frequent dosing is required to minimize adverse effects.

For patients previously treated with levodopa, allow at least 12 hours to elapse and initiate 'Prolopa' at $15 \%$ of previous levodopa dosage.

During maintenance, reduce dosage slowly, if possible to a maximum of $600 \mathrm{mg}$ levodopa daily.

\section{Supply}

'Prolopa' $50-12.5$ capsules containing $50 \mathrm{mg}$ levodopa and $12.5 \mathrm{mg}$ benserazide

'Prolopa' 100-25 capsules containing $100 \mathrm{mg}$ levodopa and $25 \mathrm{mg}$ benserazide

'Prolopa' 200-50 capsules containing $200 \mathrm{mg}$ levodopa and $50 \mathrm{mg}$ benserazide.

Bottles of 100

Product Monograph available on request.

References:

1. Editorial Parkinson's disease. 1984. Lancet 1984;1: 829-30

2. Lieberman AN, Goldstein M. Gopmathan G, et a Combined use of benserazide and carbidopa in Parkinson's disease. Neurology 1984;34:227-9

3. Rinne UK. Mölsä $P$. Levodopa with benserazide or carbidopa in Parkinson's disease. Neurology 1979: 29:1584-9.

4. Weiner WJ. Nausieda PA. Carbidopa - levodopa ratio in Parkinson's disease. Arch Neurol 1981: 38:534

5. Hoehn MM. Increased dosage of carbidopa in patients with Parkinson's disease receiving low doses of levodopa. A pilot study. Arch Neurol 1980; 37:146-9.

\section{Hoffmann-La Roche Limited}

Etobicoke, Ontario M9C 5J4

(1) Registered Trade Mark

Copyright 1985 Hoffmann-La Roche Limited

PAAB
C'PPP

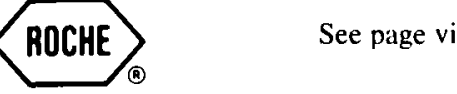

Original Research in Medicine and Chemistry

\section{BRIEF PRESCRIBING INFORMATION

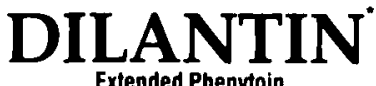 \\ Extended Phenytoin \\ Sodium Capsules, U.S.P \\ $100 \mathrm{mg}$ \\ ANTICONVULSANT}

\section{INDICATIONS}

Dilantin is indicated for the control of generalized tonic-clonic (grand mal) seizures and complex partial (psychomotor) seizures.

\section{CONTRAINDICATIONS}

Dilantin is contraindicated in those patients with a history of hypersensitivity to hydantoin products.

\section{WARNINGS}

Abrupt withdrawal of phenytoin in epileptic patients may precipitate status epilepticus.

Phenytoin is not indicated in seizures due to hypoglycemia or other causes which may be immediately identified and corrected

Phenytoin metabolism may be significantly altered by the concomitant use of other drugs such as:

A. Barbiturates may enhance the rate of metabolism of phenytoin. This effect, however, is variable and unpredictable. It has been reported that in some patients the concomitant administration of carbamazepine resulted in an increased rate of phenytoin metabolism.

B. Coumarin anticoagulants, disulfiram. phenylbutazone, and sulfaphenazole may inhibit the metabolism of phenytoin, resulting in increased serum levels of the drug. This may lead to an increased incidence of nystagmus, ataxia, or other toxic signs.

C. Isoniazid inhibits the metabolism of phenytoin so that with combined therapy, patients who are slow acetylators may suffer from phenytoin intoxication.

D. Tricyclic antidepressants in high doses may precipitate seizures, and the dosage of phenytoin may have to be adjusted accordingly. Usage in Pregnancy: The effects of Dilantin in human pregnancy and nursing infants are unknown.

The prescribing physician will have to determine the risk/benefit in treating or counselling epileptic women of childbearing potential.

\section{PRECAUTIONS}

The liver is the chief site of biotransformation of phenytoin, patients with impaired live function may show early signs of toxicity. Elderly patients or those who are gravely ill may show early signs of toxicity.

A small percentage of individuals who have been treated with phenytoin have been shown o metabolize the drug slowly. Slow metabo lism may be due to limited enzyme availability and lack of induction; it appears to be genetically determined.

Phenytoin has been associated with reversible lymph node hyperplasia. If lymph node enlargement occurs in patients on phenytoin every eftort should be made to substitute another anticonvulsant drug or drug combination.

Orugs that control generalized tonic-clonic (grand mal) seizures are not effective for absence (petit mal) seizures. Therefore, i both conditions are present. combined drug therapy is needed.

Hyperglycemia, resulting from the drug's innibitory effect on insulin release, has been reported Phenytoin may also raise the blood sugar level in persons already suffering from hyperglycemia.

\section{ADVERSE REACTIONS}

Central Nervous System: The most common manifestations encountered with phenytoin therapy include nystagmus, ataxia, slurred speech, and mentai confusion. Dizziness insomnia, transient nervousness, moto twitchings, and headache have also been observed. These side effects may disappea with continuing therapy at a reduced dosage level.

Gastrointestinal System: Phenytoin may cause nausea, vomiting, and constipation. Administration of the drug with or immediately after meals may help prevent gastrointes tinal discomfort

Integumentary System: Dermatologica manifestations sometimes accompanied by fever have included scarlatiniform or morbilform rashes.

Hemopoietic System: Hemopoietic complications some fatal have occasionally been reported in association with administration of phenytoin. These have included thrombocytopenia, leukopenia, granulocytopenia agranulocytosis, and pancytopenia.

Other: Gingival hyperplasia occurs fre quently; this incidence may be reduced by good oral hygiene including gum massage frequent brushing and appropriate denta care. Polyarthropathy and hirsutism occu occasionally. Hyperglycemia has been reported. Toxic hepatitis, liver damage and periarteritis nodosa may occur and can be fatal.

\section{MANAGEMENT OF OVERDOSAGE}

The mean lethal dose in adults is estimated to be 2 to 5 grams. The cardinal initia symptoms are nystagmus, ataxia and dysarthria. The patient then becomescomatose the pupils are unresponsive and hypotension occurs. Death is due to respiratory depres sion and apnea. Treatment is nonspecific since there is no known antidote First, the stomach should be emptied. If the gag reflex is absent, the airway should be supported. Oxygen, vasopressors and assisted ventilation may be necessary for central nervous system, respiratory and cardiovascular

depression. Finally, hemodialysis can be considered since phenytoin is not completely bound to plasma proteins.

\section{DOSAGE AND ADMINISTRATION}

Dosage should be individualized to provide maximum benefit. In some cases, senumblood level determinations may be necessary for optimal dosage adjustments - the clinically effective serum level is usually $10-20 \mathrm{mcg} / \mathrm{mL}$

Adult Dose: Patients who have received no previous treatment may be started on one 100 mo Dilantin Capsule three times daily and the dose then adjusted to suit individual requirements.

Pediatric Dose: Initially, $5 \mathrm{mg} / \mathrm{kg} /$ day in two or three equally divided doses, with subse. quent dosage individualized to a maximum of $300 \mathrm{mg}$ daily. A recommended daily maintenance dosage is usually 4 to $8 \mathrm{mg} / \mathrm{kg}$. Children over 6 years old may require the minimum adult dose (300 mg/day). Pediatric dosage forms available include a $30 \mathrm{mg}$ Capsule, a $50 \mathrm{mg}$ palatably flavoured Infatab, or an oral suspension form containing 30 or 125 $\mathrm{mg}$ of Dilantin in each $5 \mathrm{~mL}$.

Alternative Dose: Once-a-day dosage for adults with $300 \mathrm{mg}$ of Dilantin may be considered if seizure control is established with divided doses of three $100 \mathrm{mg}$ Capsules daily. HOW SUPPLIED

Dilantin $100 \mathrm{mg}$ Capsules; in bottles of $100 \&$ 


\section{Neuromatic 2000 - a proven success}
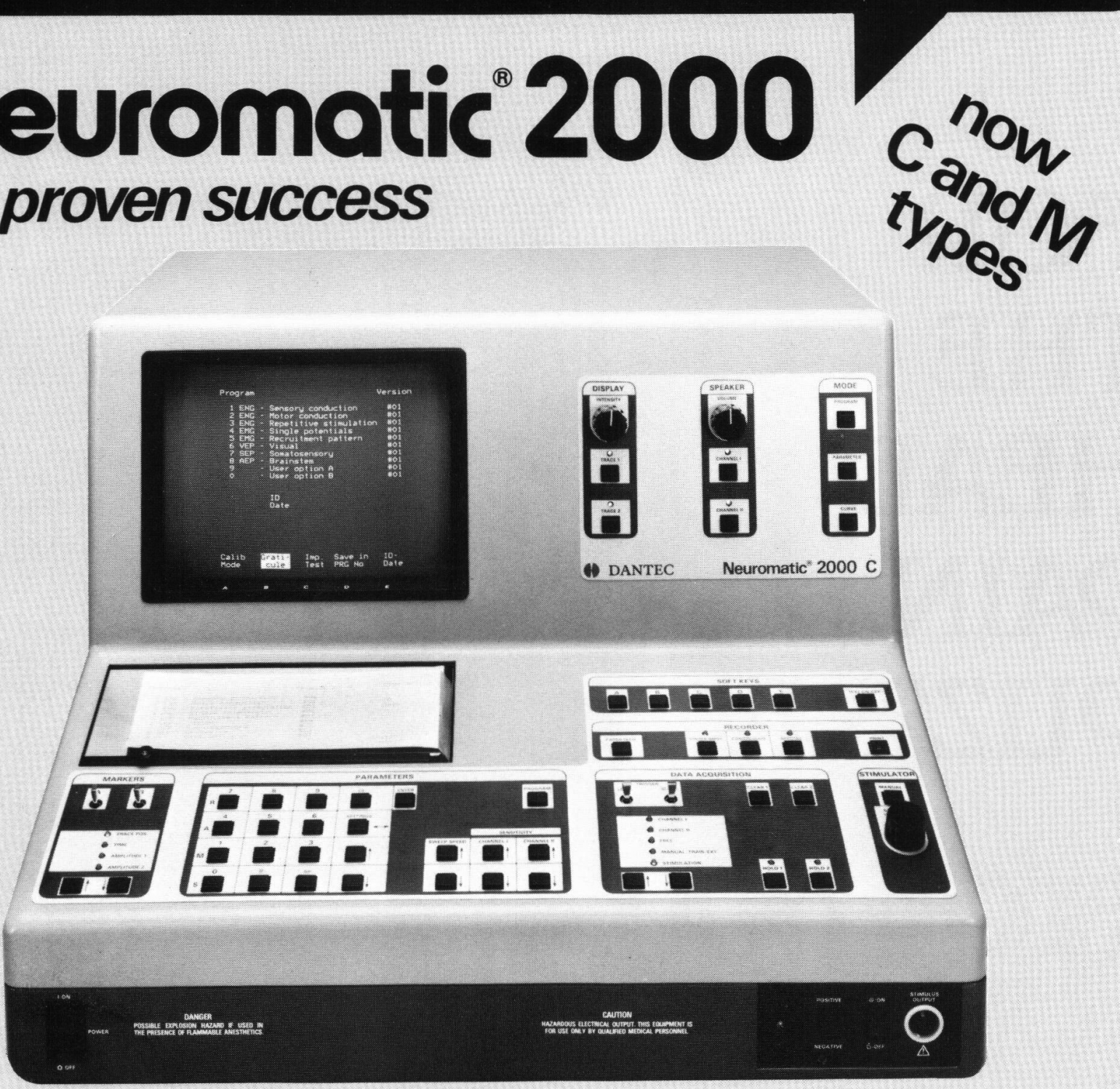

Neuromatic ${ }^{\circledR} 2000 \mathrm{C}$ - the Combined NeuroMyograph for Clinical Electromyography and Evoked Potentials

The Neuromatic ${ }^{\circledR} 2000 \mathrm{C}$ has powerful averagers with rejection facility, auditory stimulator with masking and visual stimu-

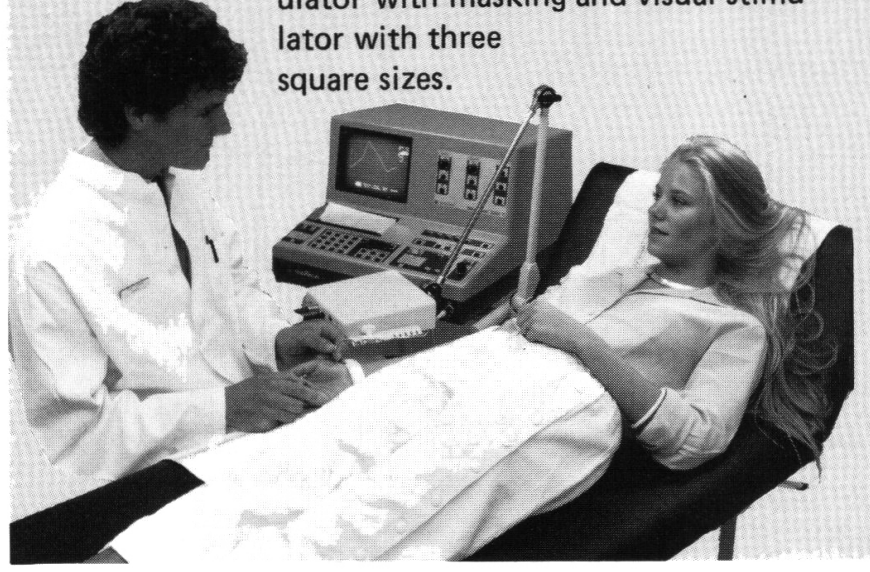

Neuromatic ${ }^{\circledR} 2000 \mathrm{M}$-the Myograph for Clinical Electromyography

The Neuromatic ${ }^{\circledR} 2000 \mathrm{M}$ has superior amplifiers and powerful averagers with rejection facility. Both the C-type and the M-type can be supplied with IEEE Interface for any standard computer.

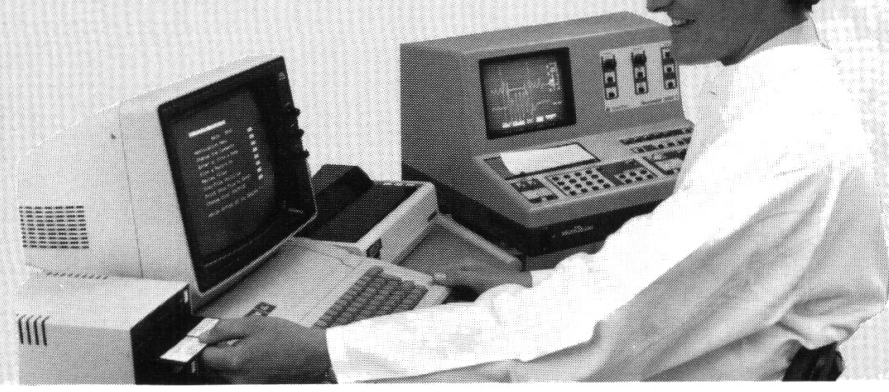




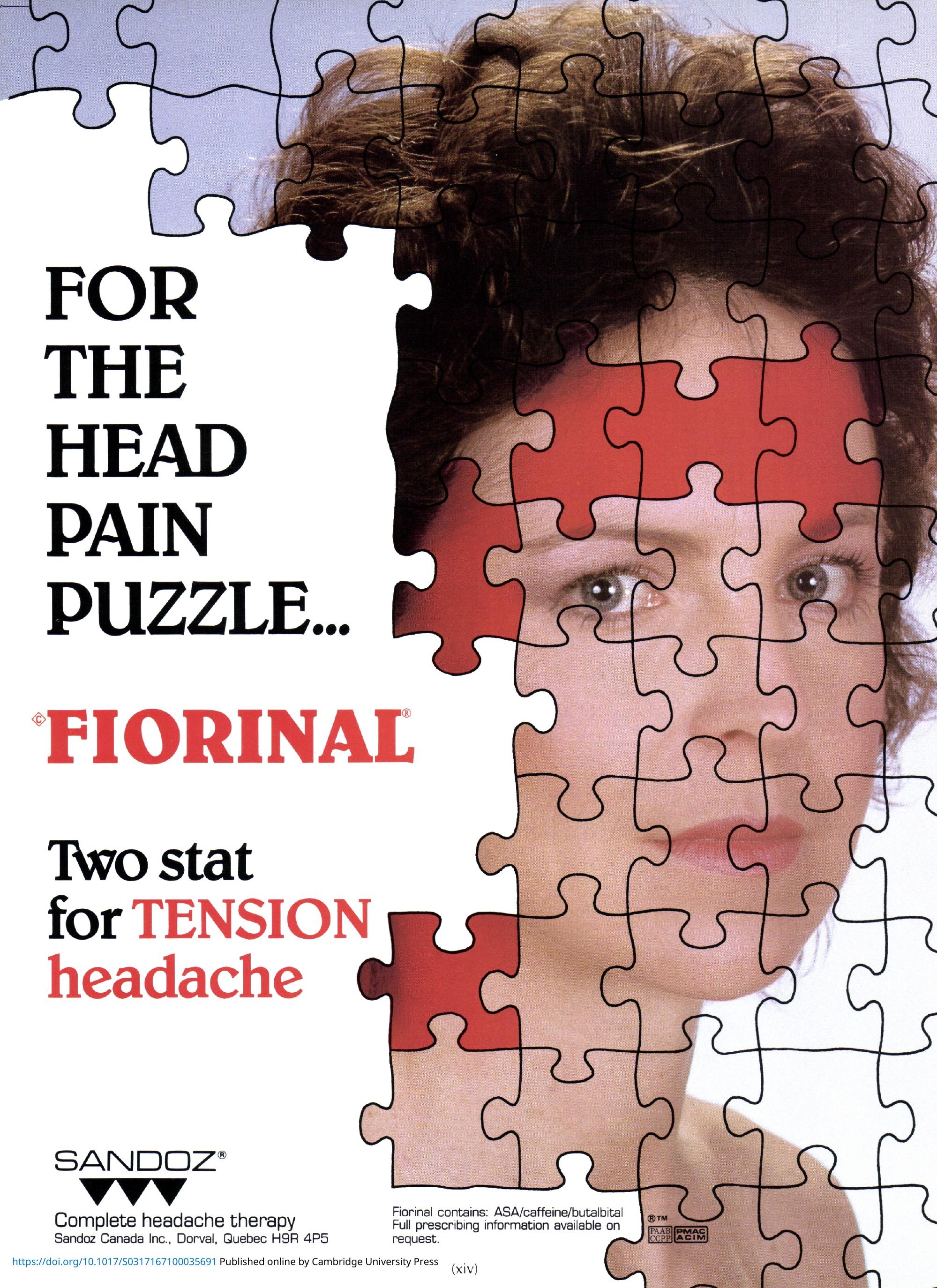

